Jap. J. M. Sc. \& Biol., 14, 157-172, 1961

\title{
HUMAN TOXOPLASMOSIS, PARTICULARLY ON THE POSSIBLE SOURCE OF ITS INFECTION IN JAPAN : A REVIEW
}

\author{
YOSHITAKA KOMIYA, AKIO KOBAYASHI \\ AND TSUTOMU KOYAMA \\ Department of Parasitology, National Institute of Health, Tokyo
}

(Received: August 30th, 1961)

Toxoplasma gondii was first found in Ctenodactylus gondii by Nicolle and Manceaux (1908) in North Africa. In the same year, Mine found an unknown species of protozoa from the liver of a mole in Japan (Mine, 1911) and Prowazek (1910) identified it as Toxoplasma. Since then this protozoa has been found from various wild animals in Japan.

In 1937-1939 Wolf et al. reported a new case of encephalomyelitis of a child due to Toxoplasma infection (Wolf et al., 1937, 1939). So this worm drew the attention of medical men as a cause of human disease and since then cases of human toxoplasmosis with obvious clinical symptoms have been reported by various workers in different countries.

In Japan, the first case of human toxoplasmosis was recorded only recently by Miyagawa et al. (1954), and since then many papers on Toxoplasma and toxoplasmosis have been published by various workers. The following is the summary of the studies on human toxoplasmosis and its possible source of infection in Japan.

\section{Human Toxoplasma Infection in Japan}

It is well known that among the persons who acquire Toxoplasma infection very few can manifest obvious clinical symptoms and a large majority can survive without manifesting any clinical symptom. Two serological procedures are currently applied in Japan in making the indirect diagnosis of the present and past toxoplasmosis.

One is the dye test (Sabin-Feldman's test) and the other is the skin test (toxoplasmin reaction). The positive case of the former indicates either the active case of toxoplasmosis or that which had passed its infection recently, whereas the latter becomes positive when the person tested had Toxoplasma infection in the past.

Table 1 gives the results of both tests made in Japan by several workers. The results of the dye test revealed that the average rate of the positive amounted to about $6-7 \%$, at the titer of more than $1: 16$.

In the case of the intradermal skin test, the toxoplasmin produced by the Institute of the Infectious Diseases, Tokyo, was used by all workers. The results showed that the positive rate varied from $8.2 \%$ to $23.9 \%$, representing about $15 \%$ on average.

Table 2 shows the results of the dye test by the workers of different countries. As seen from the Table, the rate of the positive was different from country to country,

小宮義孝・小林昭夫 - 小山力（国立予防衛生研究所寄生虫部） 
Table 1. Frequency of toxoplasma antibodies among normal human populations in Japan

\begin{tabular}{|c|c|c|c|c|c|c|c|}
\hline \multirow{2}{*}{ Method } & \multirow{2}{*}{ Author } & \multirow{2}{*}{ Year } & \multirow{2}{*}{$\begin{array}{l}\text { Part of } \\
\text { Japan }\end{array}$} & \multirow{2}{*}{$\begin{array}{l}\text { Number } \\
\text { tested }\end{array}$} & \multicolumn{2}{|c|}{ Positive*** } & \multirow{2}{*}{$\begin{array}{c}\text { Age group } \\
\text { (years) }\end{array}$} \\
\hline & & & & & No. & Per cent & \\
\hline \multirow{4}{*}{$\mathrm{DT}^{*}$} & $\begin{array}{l}\text { Hasegawa } \\
\text { et al. }\end{array}$ & 1954 & $\begin{array}{l}\text { East, Middle, } \\
\text { South zone }\end{array}$ & 483 & 35 & 7.2 & mostly $20-40$ \\
\hline & $\begin{array}{l}\text { Tsunematsu } \\
\text { et al. }\end{array}$ & 1958 & Various zones & 580 & 39 & 6.7 & $\prime \prime$ \\
\hline & $\begin{array}{l}\text { Shimizu } \\
\text { et al. }\end{array}$ & $1958 b$ & East zone & 512 & 32 & 6.2 & \multirow[t]{2}{*}{ above 10} \\
\hline & Totals & & & 1,575 & 106 & 6.7 & \\
\hline \multirow{6}{*}{$\mathrm{ST}^{* *}$} & $\begin{array}{l}\text { Kagawa } \\
\text { et al. }\end{array}$ & 1954 & $\begin{array}{l}\text { East, Middle } \\
\text { zone }\end{array}$ & 581 & 139 & 23.9 & differ. ages \\
\hline & $\begin{array}{l}\text { Tanaka } \\
\text { et al. }\end{array}$ & $1958 \mathrm{a}$ & North-East zone & 88 & 21 & 23.8 & $\prime \prime$ \\
\hline & $\begin{array}{l}\text { Koike } \\
\text { et al. }\end{array}$ & 1960 & East zone & 457 & 79 & 17.3 & $20-60$ \\
\hline & Otsuru & 1961 & North-East zone & 917 & 75 & 8.2 & \multirow{3}{*}{$\begin{array}{c}\text { differ. ages } \\
\prime \prime\end{array}$} \\
\hline & $\begin{array}{l}\text { Kobayashi } \\
\text { et al. }\end{array}$ & 1961 & East zone & 458 & 72 & 15.7 & \\
\hline & Totals & & & 2,501 & 386 & 15.4 & \\
\hline
\end{tabular}

* DT : Sabin-Feldman's dye-test.

** ST : Toxoplasmin skin-test.
Dye test titer 1 in 16 or more (DT). Erythema-diameter $10 \mathrm{~mm}$ or more (ST).

Table 2. Comparative incidence of dye test antibodies among 7 normal population groups

\begin{tabular}{|c|c|c|c|c|c|c|c|c|}
\hline \multirow{2}{*}{\multicolumn{2}{|c|}{$\begin{array}{c}\text { Age } \\
\text { group }\end{array}$}} & \multicolumn{2}{|c|}{ Japan } & \multirow{2}{*}{$\begin{array}{c}\text { Freiburg } \\
\text { Keller } \\
\text { et al. } \\
1952 \\
(\geqq \times 25)\end{array}$} & \multirow{2}{*}{$\begin{array}{c}\text { Sheffield } \\
\text { Beverley } \\
\text { et al. } \\
1954 \\
(\geqq \times 16)\end{array}$} & \multirow{2}{*}{$\begin{array}{c}\frac{\text { Leipzig }}{\text { Wildführ }} \\
(\geqq \times 54 \\
(\geqq \times 16)\end{array}$} & \multirow{2}{*}{$\begin{array}{c}\text { U.S.A. } \\
\text { Feldman } \\
\text { et al. } \\
1956 \\
(\geqq \times 16)\end{array}$} & \multirow{2}{*}{$\begin{array}{c}\text { Helsinki } \\
\text { Grönroos } \\
1955 \\
(\geqq \times 16)\end{array}$} \\
\hline & & $\begin{array}{l}\text { Tsunematsu } \\
\text { et al. 1958 } \\
\quad(\geqq \times 16)\end{array}$ & $\begin{array}{c}\text { Shimizu } \\
\text { et al. } 1958 \mathrm{~b} \\
(\geqq \times 16)\end{array}$ & & & & & \\
\hline \multirow{2}{*}{\multicolumn{2}{|c|}{$\begin{array}{l}\text { Newborn } \\
1-5 \text { months }\end{array}$}} & $\%$ & $\%$ & $\begin{array}{l}\% \\
54(50)\end{array}$ & $\%$ & $\%$ & $\%$ & $\%$ \\
\hline & & & & $2(66)$ & & & & \\
\hline \multirow{2}{*}{\multicolumn{2}{|c|}{$1-10$ years }} & $0(5)$ & & $4(53)$ & $1.9(108)\}$ & $6.7(75)$ & $17(445)$ & $6.1(66)$ \\
\hline & & & & $17(82)$ & & & & $5.4(149)$ \\
\hline $10-20$ & $"$ & $3.6(55)$ & $5.9(67)$ & $20(127)$ & $7.3(55)$ & $2.1(143)$ & $32(298)$ & $17.2(58)$ \\
\hline $20-30$ & $"$ & $5.1(257)$ & $5.6(142)$ & 23(327) & $5.9(101)$ & $1.3(152)$ & $34(273)$ & $18.0(444)$ \\
\hline $30-40$ & $"$ & $12.5(112)$ & $6.0(182)$ & $22(170)$ & $1.9(105)$ & $3.1(257)$ & $38(253)$ & $27.1(225)$ \\
\hline $40-50$ & $"$ & $6.3(95)$ & $7.4(81)$ & $19(74)$ & $3.8(108)$ & $1.3(380)$ & $39(223)$ & $31.6(79)$ \\
\hline $50-60$ & $"$ & $0(14)$ & $7.5(40)$ & & & $0.6(170)$ & & $33.3(75)$ \\
\hline $60-$ & $"$ & $0(2)$ & & $21(75)$ & $2.9(104)$ & $0.0(28)$ & $38(255)$ & $17.2(58)$ \\
\hline
\end{tabular}

( ) just below author's names indicate the dilution limit of sera for a positive dye test. ( ) in table indicate number of test-subjects.

those in U. S. A. showing a relatively high percentage (20-40\%) as compared with that in Japan (4-13\%).

Table 3 shows the results of the toxoplasmin test in different countries according to the age groups. The results revealed that the rate of the positive in Japan gave a rather low percentage as compared with those in the other countries. It is to be noticed here that the rate of the positive for the skin test was inclined to increase as 
the age was advanced. It seems natural to consider that the results of the skin test suggested the past infection. The skin test among the age groups of above 30 years showed the rate of the positive amounted to $20-30 \%$. This means that $20-30 \%$ of the Japanese in this age group had experienced at least once the Toxoplasma infection in the past.

Table 3. Comparative incidence of Toxoplasmin skin test antibodies among 6 normal population groups

\begin{tabular}{|c|c|c|c|c|c|c|}
\hline \multirow[b]{2}{*}{$\begin{array}{l}\text { Age group } \\
\text { (years) }\end{array}$} & \multicolumn{2}{|c|}{ Japan } & \multirow{2}{*}{$\begin{array}{c}\text { Cincinnati } \\
\text { (U.S. A.) } \\
\begin{array}{c}\text { Sabin \& } \\
\text { Feldman } \\
1949\end{array}\end{array}$} & \multirow{2}{*}{$\begin{array}{c}\begin{array}{c}\text { London } \\
\text { (England) }\end{array} \\
\text { Fisher } \\
1951\end{array}$} & \multirow{2}{*}{$\begin{array}{c}\begin{array}{c}\text { Stocknolm } \\
\text { (Sweden) }\end{array} \\
\text { Gard } \\
1951\end{array}$} & \multirow{2}{*}{$\begin{array}{c}\begin{array}{c}\text { Eskilstuna } \\
\text { (Sweden) }\end{array} \\
\text { Hedqvist } \\
1953\end{array}$} \\
\hline & $\begin{array}{c}\text { Kagawa } \\
\text { et al. } \\
1954\end{array}$ & $\begin{array}{c}\text { Kobayashi } \\
\text { et al. } \\
1961\end{array}$ & & & & \\
\hline $0-4$ & $\%$ & $\%(23)$ & $\begin{array}{l}\% \\
0(20)\end{array}$ & $0.5(186)$ & $\begin{array}{l}\% \\
3.5(537)\end{array}$ & $\begin{array}{l}\% \\
0(201)\end{array}$ \\
\hline $5-9$ & $13.8(94)$ & $4.7(107)$ & $5(20)$ & $4.3(322)$ & $6.5(123)$ & $1(104)$ \\
\hline $10-14$ & & & & $7.0(216)$ & $21.0(42)$ & $0(74)$ \\
\hline $15-19$ & $13.8(36)$ & $4.3(115)$ & $14(20)$ & & $45.0(40)$ & $22(73)$ \\
\hline $20-29$ & $18.0(249)$ & $4.5(22)$ & $20(20)$ & & $45.0(332)$ & $34(122)$ \\
\hline $30-50$ & $32.4(71)$ & $27.7(101)$ & $57(40)$ & & $50.0(374)$ & $47(74)$ \\
\hline $20-50$ & $21.3(320)$ & $23.6(123)$ & $45(60)$ & $33.0(59)$ & $48.0(706)$ & $40(196)$ \\
\hline
\end{tabular}

( ): Number of test-subjects.

\section{Human Toxoplasmosis Manifesting Obvious Clinical Symptoms}

As already mentioned above, the first case of human toxoplasmosis manifesting obvious symptoms was reported by Miyagawa $e t$ al. in 1954 . Since then have been reported by various workers 37 cases of human toxoplasmosis representing obvious clinical symptoms. Toxoplasma could be isolated from all of the cases by successive mouse inoculation. Among them 14 cases were under 1 year of age and 4 cases above 20 years of age. Table 4 shows the records of those patients. The predominant clinical symptoms were hydrocephalus, cleft palate, prolapse of the meninges and brain, convulsion and mental weakness due to the disorder of the central nervous system.

\section{Several Diseases and Toxoplasma Infection}

As already mentioned, the isolation of Toxoplasma from the patients of certain diseases suggested that this protozoa could produce various pathological changes and clinical symptoms. Thus recently the correlation between several diseases and Toxoplasma infection has been studied by several workers in Japan. Table 5 shows the results of the positive rate for the dye test or for the skin test among several diseases.

The results revealed that among various diseases the rate of the positive in the case of disease in the eye ground showed the highest percentage, which was succeeded by those of eye disease and those suffering from nervous diseases and mental diseases. The positive incidence among those suffering from tuberculosis showed a rather lower rate as compared with that of the other groups.

\section{Toxoplasmosis among Domestic Animals}

Since 1954 the dye or skin test among the various domestic animals in Japan has been carried out by several workers, of which the results are shown in Table 6 along with those of the other countries. 
Table 4. Published cases of human toxoplasmosis parasitologically confirmed in Japan (from 1954 to present)

\begin{tabular}{|c|c|c|c|c|c|c|}
\hline \multirow[b]{2}{*}{ No. } & \multirow[b]{2}{*}{ Age } & \multirow[b]{2}{*}{ Sex } & \multirow[b]{2}{*}{ Symptoms } & \multicolumn{2}{|c|}{$\begin{array}{c}\text { Procedure of } \\
\text { detecting parasite } \\
\end{array}$} & \multirow{2}{*}{ Reporter } \\
\hline & & & & $\begin{array}{l}\text { Cerebro- } \\
\text { spinal } \\
\text { fluid }\end{array}$ & Mice & \\
\hline 1 & 5 years & ? & Inability to walk & + & 1st p. & Miyazaki et al. \\
\hline 2 & 12 years & $\delta$ & Mental disturbance, Spastic fits & + & $"$ & \\
\hline 3 & 3 months & o & $\begin{array}{l}\text { Deformed upper lip } \\
\text { (Hare-lip, Cleft palate) }\end{array}$ & + & $"$ & $\begin{array}{l}\text { Hiraoka } \\
\quad(1957 \mathrm{a}, \mathrm{b})\end{array}$ \\
\hline 4 & 7 years & $\hat{o}$ & $\begin{array}{l}\text { Head-ache, Vomiting, Lassitude, } \\
\text { Somnolence, Incontinence }\end{array}$ & + & $"$ & \\
\hline 5 & 8 years & ㅇ & $\begin{array}{l}\text { Retarded mental development, } \\
\text { Senselessness }\end{array}$ & + & $"$ & \\
\hline 6 & 7 years & $\hat{o}$ & $\begin{array}{l}\text { Speech disorder, Convulsion, } \\
\text { Dementia }\end{array}$ & + & " & \\
\hline 7 & 6 years & ᄋ & $"$ & + & $"$ & \\
\hline 8 & 16 years & $\hat{o}$ & " & + & " & \\
\hline 9 & 12 years & q & Weak-mindedness & + & $"$ & \\
\hline 10 & 13 years & $\delta$ & " & + & " & \\
\hline 11 & 39 years & $\delta$ & Motor and Speech-disturbance & & " & \\
\hline 12 & 4 years & \& & Schizophrenia & & 4 th $\mathrm{p}$. & Yamamoto \\
\hline 13 & 6 months & ? & Palatine-disruption, Hydrocephalus & & 2nd $\mathrm{p}$. & \\
\hline 14 & 22 days & ? & $\begin{array}{l}\text { Meningo-encephalocele, } \\
\text { Hydrocephalus }\end{array}$ & & 4th $\mathrm{p}$. & \\
\hline 15 & 4 years & $\delta$ & $\begin{array}{l}\text { Growth disturbance, Degeneratio } \\
\text { maculae lutae }\end{array}$ & & 2nd p. & \\
\hline 16 & 29 years & $\hat{o}$ & Central chorioretinitis & & 4 th $\mathrm{p}$ & \\
\hline 17 & 47 years & o & Motor and Speech-disturbance & & 1st p. & \\
\hline 18 & 11 years & s & Hydrocephalus & + & + & Miyagawa \\
\hline 19 & 8 years & $\hat{o}$ & $\begin{array}{l}\text { Hydrocephalus, Weak-mindedness, } \\
\text { Convulsion }\end{array}$ & + & + & $\begin{array}{l}\text { et al. (1954) } \\
\text { (Quoted from } \\
\text { Matsubayashi, }\end{array}$ \\
\hline 20 & 40 days & & Hydrocephalus & + & + & 1959) \\
\hline 21 & 14 months & $\hat{o}$ & Hydrocephalus (Autopsy) & $\begin{array}{l}\text { Microsecti } \\
\text { brain }\end{array}$ & ion of & \\
\hline 22 & 6 months & Fetus & $\begin{array}{l}\text { Abortion due to excessive amniotic } \\
\text { fluid }\end{array}$ & " & & \\
\hline 23 & 13 years & o & Weak-mindedness, Epilepsy & - & 3rd p. & $\begin{array}{l}\text { Otsuru et al. } \\
\quad(1958,1960 \mathrm{a})\end{array}$ \\
\hline 24 & 27 years & \& & Meningitis, Convulsion & + & 2nd p. & \\
\hline 25 & 48 days & $\hat{o}$ & Hydrocephalus, Convulsion & $\begin{array}{l}\text { Microsect } \\
\text { brain an }\end{array}$ & $\begin{array}{l}\text { ions of } \\
\text { hd spleen }\end{array}$ & $\underset{(1958 \mathrm{a})}{\operatorname{Shimizu}}$ et $a l$. \\
\hline 26 & 35 days & q & Hydrocephalus & - & + & \\
\hline 27 & 2 days & & $"$ & & 2nd p. & Shimizu (1961) \\
\hline $\begin{array}{l}28 \\
29\end{array}$ & $\begin{array}{l}5 \text { months } \\
17 \text { years }\end{array}$ & $\begin{array}{l}\text { Fetus } \\
\wp\end{array}$ & $\begin{array}{l}\text { Macerated child } \\
\text { Hydrocephalus, Weak-mindedness }\end{array}$ & & $\begin{array}{l}\text { 1st p. } \\
\text { 3rd p. }\end{array}$ & \\
\hline 30 & 3 years & $\hat{\delta}$ & $\begin{array}{l}\text { Tuberculous meningitis, } \\
\text { Hydrocephalus }\end{array}$ & $\begin{array}{l}\text { Microsect } \\
\text { brain }\end{array}$ & ion of & $\begin{array}{l}\text { Matsubayashi } \\
\quad(1959)\end{array}$ \\
\hline 31 & 11 years & ô & Fever, Head-ache & - & 1st p. & \\
\hline 32 & 9 months & o & Hydrocephalus, Meningocele & - & $"$ & \\
\hline 33 & 2 months & $\hat{o}$ & Hydrocephalus (Autopsy) & - & " & \\
\hline 34 & 2 years & $\hat{o}$ & $\begin{array}{l}\text { Ptosis of eye-lid, Paralysis of } \\
\text { N. oculomotorius }\end{array}$ & - & $"$ & \\
\hline 35 & 7 months & o & Hydrocephalus & + & " & Saito (1961) \\
\hline 36 & 10 years & $q$ & Head-ache & & 1st p. & $\underset{(1961)}{\text { Tanaka }}$ et al. \\
\hline 37 & 10 months & Fetus & Hydrocephalus & & $"$ & $\underset{(1961)}{\text { Johno } e t \text { al. }}$ \\
\hline
\end{tabular}

p.-passage (inoculation). 
Table 5. Incidence of toxoplasma antibodies among various patient groups

\begin{tabular}{|c|c|c|c|c|c|c|c|}
\hline Disease & Author & Year $\quad$ Yearted & Method & $\begin{array}{l}\text { Number } \\
\text { tested }\end{array}$ & $\begin{array}{l}\text { Number } \\
\text { positive }\end{array}$ & $\begin{array}{c}\% \\
\text { positive }\end{array}$ & $\begin{array}{c}\text { Notes } \\
\text { (Age by yrs.) }\end{array}$ \\
\hline $\begin{array}{l}\text { Diseases of } \\
\text { eye-ground }\end{array}$ & $\begin{array}{l}\text { Tsunematsu } \\
\text { et al. }\end{array}$ & 1958 & DT & 69 & 25 & 36.2 & mostly $20-40$ \\
\hline " & Matsubayashi & 1960 & $"$ & 42 & 10 & 23.8 & \\
\hline Ocular diseases & $\begin{array}{l}\text { Miyazaki } \\
\text { et al. }\end{array}$ & 1960 & ST & 119 & 22 & 18.5 & \\
\hline$"$ & $\begin{array}{l}\text { Otsuru } \\
\text { et al. }\end{array}$ & 1959 & $"$ & $\Delta s$ & 12 & 25.0 & \\
\hline Hydrocephalus & $\begin{array}{l}\text { Tsunematsu } \\
\text { et al. }\end{array}$ & 1958 & DT & 22 & 1 & 4.5 & $\begin{array}{l}\text { mostly } \\
\text { below } 10\end{array}$ \\
\hline $\begin{array}{l}\text { Diseases of central } \\
\text { nervous system }\end{array}$ & " & 1958 & " & 28 & 1 & 3.6 & $\begin{array}{l}\text { children and } \\
\text { adults }\end{array}$ \\
\hline$"$ & Otsuru & 1961 & $"$ & 611 & 121 & 19.8 & below 15 \\
\hline$"$ & $\begin{array}{l}\text { Miyazaki } \\
\text { et al. }\end{array}$ & 1961 & ST & 37 & 1 & 2.7 & \\
\hline Mental diseases & $\begin{array}{l}\text { Tsuji } \\
\quad \text { et al. }\end{array}$ & 1958 & DT & 60 & 8 & 13.3 & adults \\
\hline Weak-mindedness & " & 1958 & $"$ & 65 & 12 & 18.2 & children \\
\hline $\begin{array}{l}\text { Weak-mindedness } \\
\text { and Mental } \\
\text { diseases }\end{array}$ & Otsuru & 1961 & ST & 1,298 & 257 & 19.8 & $5-70$ \\
\hline Tuberculosis & $\begin{array}{l}\text { Matsubayashi } \\
\text { et al. }\end{array}$ & $\begin{array}{l}1901 \\
1961\end{array}$ & $\begin{array}{l}\text { DT } \\
\text { ST }\end{array}$ & $\begin{array}{l}30 \hat{3} \\
322\end{array}$ & $\begin{array}{l}28 \\
31\end{array}$ & $\begin{array}{l}9.1 \\
9.6\end{array}$ & \\
\hline$"$ & Otsuru & 1961 & $"$ & 499 & 51 & 10.2 & $10-70$ \\
\hline Pregnant women & $\begin{array}{l}\text { Tsuji } \\
\text { et al. }\end{array}$ & 1958 & $\mathrm{DT}$ & 77 & 12 & 15.6 & \\
\hline $\begin{array}{l}\text { Women who have } \\
\text { had abortion }\end{array}$ & " & 1958 & $"$ & 60 & 6 & 10.0 & $2 C-40$ \\
\hline
\end{tabular}

DT : Dye-test. ST: Skin-test.

Dilution limit for dye test positive is 1 in 16 or more.

\section{a) Swine.}

The results of the dye test among the swine revealed that the rate of the positive varied from zero to $59 \%$ according to the locality where they were examined. The incidence of Niigata Prefecture showed the highest positive rate among the localities.

Very recently Suzuki et al. (1960) made the complement fixation inhibition test on swine sera collected from various prefectures in Japan. The results are shown in Table 7 , which indicates that the average rate of the positive (titer 1 in 8 or more) amounted to $8.6 \%$. The positive rate had the tendency to increase as the age of the swine became older. Fig. 1 shows the incidence rate of the positive in different prefectures.

b) Cattle, goats and sheep.

The incidence rate of the positive for dye test among the cattle varied from 3 to $65 \%$ according to the localities, that of Tokyo giving the highest incidence.

The positive incidence among goats revealed the highest among the domestic animals, representing from 38.1 to $85 \%$. The incidence of the positive among sheep showed a rather moderate rate.

c) Dogs.

As the results of the dye test among dogs, two data are available in Japan. According to them the rate of the positive among dogs varied from 20.4 to $52.2 \%$. It is to be noticed that toxoplasmosis among dogs has been regarded rather important because dogs have closer contact with human as its pet and thus can serve as a source of human toxoplasmosis. 
Table 6. Frequency of toxoplasma antibodies among domestic animals

\begin{tabular}{|c|c|c|c|c|c|c|c|c|}
\hline Animal & Author & Year & Place & Method & $\begin{array}{l}\text { No. } \\
\text { test. }\end{array}$ & $\begin{array}{l}\text { No. } \\
\text { posi. }\end{array}$ & $\begin{array}{c}\% \\
\text { posi. }\end{array}$ & Notes \\
\hline \multirow[t]{5}{*}{ Swine } & $\begin{array}{l}\text { Hasegawa } \\
\text { et al. }\end{array}$ & 1954 & $\begin{array}{l}\text { Japan } \\
\text { (Fukushima) }\end{array}$ & $\mathrm{DT}$ & 31 & 0 & 0 & $\geqq \times 16$ \\
\hline & $\begin{array}{l}\text { Feldman } \\
\text { et al. }\end{array}$ & 1956 & U. S. A. & "I & 82 & 23 & 28.0 & " \\
\hline & $\begin{array}{l}\text { Tanaka } \\
\text { et al. }\end{array}$ & $1958 \mathrm{~b}$ & $\begin{array}{l}\text { Japan } \\
\text { (Niigata) }\end{array}$ & $\prime \prime$ & 32 & 19 & 59.4 & $\prime \prime$ \\
\hline & $\begin{array}{l}\text { Eyles } \\
\text { et al. }\end{array}$ & 1959 & $\begin{array}{l}\text { U. S. A. } \\
\text { (Memphis) }\end{array}$ & $\prime \prime$ & 178 & 38 & 21.3 & $\prime \prime$ \\
\hline & $\begin{array}{l}\text { Mochizuki } \\
\text { et al. }\end{array}$ & 1960 & $\begin{array}{l}\text { Japan } \\
\text { (Shizuoka) }\end{array}$ & $\prime \prime$ & 232 & 61 & 26.3 & " \\
\hline \multirow[t]{6}{*}{ Cattle } & $\begin{array}{l}\text { Hasegawa } \\
\text { et al. }\end{array}$ & 1954 & $\begin{array}{l}\text { Japan } \\
\text { (Fukushima) }\end{array}$ & $\prime \prime$ & 35 & 1 & 2.8 & " \\
\hline & $\begin{array}{l}\text { Feldman } \\
\text { et al. }\end{array}$ & 1956 & U. S. A. & $\prime \prime$ & 156 & 25 & 16.0 & " \\
\hline & $\begin{array}{l}\text { Tanaka } \\
\text { et al. }\end{array}$ & $1958 \mathrm{~b}$ & $\begin{array}{l}\text { Japan } \\
\text { (Niigata) }\end{array}$ & " & 29 & 12 & 41.4 & "I \\
\hline & Ishii & 1959 & $\begin{array}{l}\text { Japan } \\
\text { (Tokyo) }\end{array}$ & CFIT & $\left\{\begin{array}{l}37 * \\
37\end{array}\right.$ & $\begin{array}{l}24 \\
21\end{array}$ & $\begin{array}{l}64.6 \\
56.7\end{array}$ & $\geqq \stackrel{\prime \prime}{ } \times 8$ \\
\hline & $\begin{array}{l}\text { Eyles } \\
\text { et al. }\end{array}$ & 1959 & $\begin{array}{l}\text { U. S. A. } \\
\text { (Memphis) }\end{array}$ & DT & 50 & 0 & 0 & $\geqq \times 16$ \\
\hline & $\begin{array}{l}\text { Mochizuki } \\
\text { et al. }\end{array}$ & 1960 & $\begin{array}{l}\text { Japan } \\
\text { (Shizuoka) }\end{array}$ & " & 43 & 13 & 30.1 . & "1 \\
\hline \multirow[t]{3}{*}{ Goats } & $\begin{array}{l}\text { Hasegawa } \\
\text { et al. }\end{array}$ & 1954 & $\begin{array}{l}\text { Japan } \\
\text { (Fukushima) }\end{array}$ & DT & 13 & 5 & 38.1 & $\prime \prime$ \\
\hline & $\begin{array}{l}\text { Feldman } \\
\text { et al. }\end{array}$ & 1956 & U. S. A. & " & 65 & 28 & 43.0 & $\prime \prime$ \\
\hline & $\begin{array}{l}\text { Tanaka } \\
\text { et al. }\end{array}$ & $1958 \mathrm{~b}$ & $\begin{array}{l}\text { Japan } \\
\text { (Niigata) }\end{array}$ & $\prime \prime$ & 7 & 6 & 85.7 & " \\
\hline \multirow[t]{2}{*}{ Sheep } & $\begin{array}{l}\text { Hasegawa } \\
\text { et al. }\end{array}$ & 1954 & $\begin{array}{l}\text { Japan } \\
\text { (Fukushima) }\end{array}$ & "I & 17 & 3 & 17.6 & $\prime \prime$ \\
\hline & $\begin{array}{l}\text { Eyles } \\
\text { et al. }\end{array}$ & 1959 & $\begin{array}{l}\text { U. S. A. } \\
\text { (Memphis) }\end{array}$ & "I & 29 & 7 & 24.1 & " \\
\hline \multirow[t]{7}{*}{ Dogs } & $\begin{array}{l}\text { Otten } \\
\text { et al. }\end{array}$ & 1951 & $\begin{array}{l}\text { Germany } \\
\text { (Hamburg) }\end{array}$ & $\prime \prime$ & 122 & 49 & 40.1 & $\geqq \times 25$ \\
\hline & Weinman & 1952 & U. S. A. & " & 88 & 37 & 40.2 & $\geqq \times 64$ \\
\hline & $\begin{array}{l}\text { Cole } \\
\text { et al. }\end{array}$ & 1953 & $\begin{array}{l}\text { U. S. A. } \\
\text { (Ohio) }\end{array}$ & ST & 1,944 & 76 & 3.9 & \\
\hline & $\begin{array}{l}\text { Feldman } \\
\text { et al. }\end{array}$ & 1956 & U.S. A. & DT & 132 & 57 & 43.1 & $\geqq \times 16$ \\
\hline & $\begin{array}{l}\text { Shimada } \\
\text { et al. }\end{array}$ & 1956 & $\begin{array}{l}\text { Japan } \\
\text { (Tokyo) }\end{array}$ & " & 93 & 19 & 20.4 & " \\
\hline & $\begin{array}{l}\text { Tanaka } \\
\text { et al. }\end{array}$ & $1958 \mathrm{~b}$ & $\begin{array}{l}\text { Japan } \\
\text { (Niigata) }\end{array}$ & $\prime \prime$ & 46 & 24 & 52.2 & " \\
\hline & $\begin{array}{l}\text { Eyles } \\
\text { et al. }\end{array}$ & 1959 & $\begin{array}{l}\text { U. S. A. } \\
\text { (Memphis) }\end{array}$ & " & 809 & 130 & 16.1 & " \\
\hline
\end{tabular}

DT : Dye-test.

ST : Skin-test.

CFIT : Complement fixation inhibition test.

* tested on the same sera. 
Table 7 (a). Frequency of toxoplasma antibodies among swine (Suzuki et al., 1960)

\begin{tabular}{ccc}
\hline \multirow{2}{*}{ Number tested } & \multicolumn{2}{c}{ Positive* } \\
\cline { 2 - 3 } & No. & Per cent \\
\hline 1,891 & 162 & 8.6 \\
\hline
\end{tabular}

Table 7 (b) Distribution by age of the antibodies among swine

\begin{tabular}{lrrr}
\hline \multirow{2}{*}{ Age group } & Number tested & \multicolumn{2}{c}{ Positive* } \\
\cline { 3 - 4 } & & 7 & Por cent \\
\hline $0-6$ months & 94 & 69 & 7.4 \\
$7-12$ months & 954 & 24 & 7.2 \\
$1.1-2$ years & 155 & 13 & 15.4 \\
2.1 years or more & 107 & 113 & 12.1 \\
Totals & 1,310 &
\end{tabular}

* Complement fixation inhibition test (CFIT) titer 1 in 8 or more.

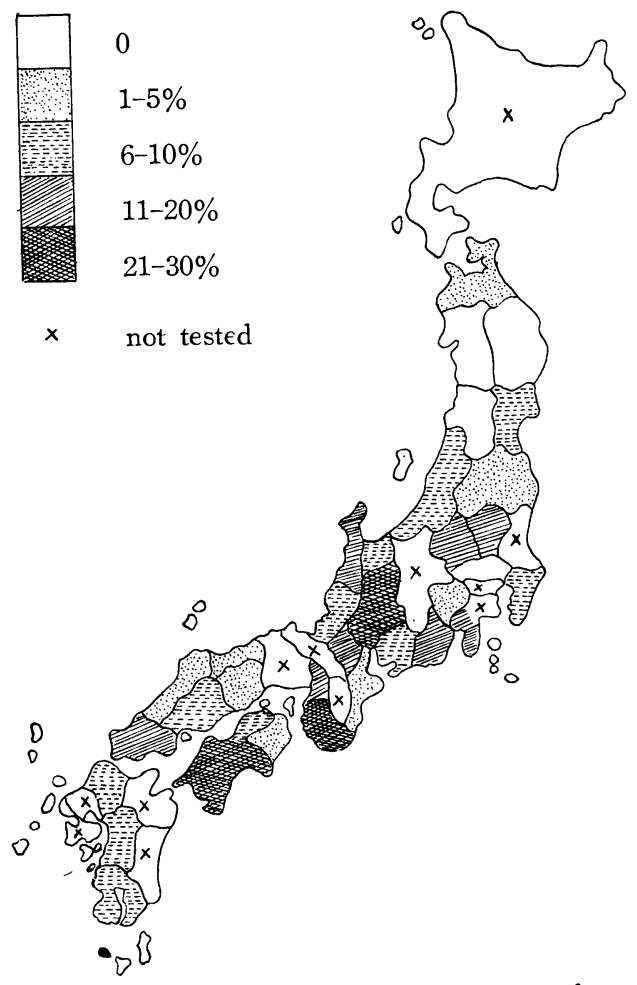

Fig. 1. Map of Japan, showing the distribution of toxoplasma antibodies among swine (Suzuki et al., 1960).

(Complement fixation inhibition test titers 1 in 8 or more are considered to be positive.) 
The first case of the dog toxoplasmosis with obvious clinical symptoms was reported in Japan by Hamada in 1951, the second one by Yamamoto et al. (1955) and the third by Sato et al. (1958). In the last case, which has also been recorded by Koike et al. (1959), a boy aged 11 complained of headache about one month after the death of his diseased dog. From the cerebrospinal fluid of this child was isolated Toxoplasma. The author thus considered that the human infection was to be originated from dogs. Cole et al. (1953) and Prior et al. (1953) reported similar cases. It is easily considered that dogs can serve as a source of human toxoplasmosis at times.

d) Swine toxoplasmosis with obvious clinical symptoms.

Recently in Japan swine toxoplasmosis with obvious clinical signs has gradually drawn the attention of veterinarians. According to Nobuto et al. (1960) an epizootic of an unknown disease has occurred among swine in Tokyo, all of which were introduced from Kanagawa Prefecture, a neighboring prefecture of Tokyo. Their symptoms were fever, cough, breast symptoms similar to pneumonia and purple spots on the ears and on the abdomen. Forty percent of them died. Their clinical symptoms were alike to those of hog cholera though they all had already been inoculated with the cholera vaccine. Penicillin treatment remained fruitless and a considerably high rate of the positive was demonstrated among them by the dye test. From 3 or 4 swine which were intentionally sacrificed for examination was isolated Toxoplasma.

Table 8. Results of survey on swine slaughtered at several abattoirs for the presence of certain pathological findings and toxoplasma (Sato, 1961)

\begin{tabular}{|c|c|c|c|}
\hline $\begin{array}{c}\text { Number of swine } \\
\text { tested }\end{array}$ & & $\begin{array}{l}\text { Number of swine with } \\
\text { path. changes }\end{array}$ & $\%$ \\
\hline 58,943 & & 131 & 0.22 \\
\hline Number of swine tested & & $\begin{array}{c}\text { Number of swine } \\
\text { harboring toxoplasma }\end{array}$ & $\%$ \\
\hline with path. changes & 131 & 82 & 63.1 \\
\hline without path. changes & 83 & 0 & 0 \\
\hline
\end{tabular}

Notes: Pathological changes.

1. Disturbance of retractility of the lung.

2. Edematous swelling of the lung.

3. Swelling of gastric, hepatic, and mesenteric lymph nodes.

Another case was reported from Shizuoka Prefecture. Here, from 1958 to 1959 an epizootic occurred and abortions of swine were recognized. The results of the dye test and complement fixation inhibition test revealed the remarkably high incidence of the positive among them. Sato (1961) collected 131 cases of swine showing the degenerative changes and edematous swelling of the lung, the swelling and hardening of lymph nodes of the stomack, liver and mesenterium. By examination of the smear specimens of their lungs Toxoplasma could be demonstrated in 82 cases $(63.1 \%)$ among them (See Table 8).

Swine toxoplasmosis is considered to be important as a cause of its human infection, because 4 times as many swine as cattle have been slaughtered since several years ago
in Japan. 
Table 9. Procedure of isolation of toxoplasma from swine muscle

$\frac{10 \mathrm{~g} \text { of diaphragm muscle }}{1}$
Washed with sterilized normal saline
$\begin{gathered}\text { Ground in household-type meat grinder } \\ \text { Filtered through } 2 \text { layers of gauze } \\ \text { Centrifuged for } 10 \text { min. at } 3000 \mathrm{rpm}\end{gathered}$

Sediment was resuspended in $2 \mathrm{cc}$ of normal saline

Mouse* was inoculated with $0.4 \mathrm{cc}$ of the suspension $(+0.1 \mathrm{cc}$ of antibiotics soln.)

Subinoculated for successive $3-5$ generations at a interval of $2-3$ weeks

Criterion for positive :

1. Finding of crescent-shaped parasite in peritoneal fluid of inoculated mice (Giemsa stained smear preparation).

2. Manifestation of signs of infection in mice (lack of appetite or drinking, coarse hair, emaciation, retention of ascites) or their death.

3. Multiplication of the parasite by successive subinoculation of mice.

4. Identification of the parasite with toxoplasma by cross-immunization test.

* Three mice were used at each meat sample.

\section{The Demonstration of Toxoplasma in Swine Meat}

The results above mentioned suggest that the meat from apparently healthy swine can contain Toxoplasma, since at times more than $50 \%$ of them had Toxoplasma antibodies in some localities. Thus from the slaughter house of Shibaura in Tokyo, the biggest one in this country, specimens of the diaphragm of apparently healthy swine were randomly collected by the authors and examined for Toxoplasma. The technic for its isolation was as follows. Every $10 \mathrm{~g}$ of the diaphragm muscle was taken, washed with sterilized normal saline, ground in the meat grinder, filtered with 2 layers of gauze and the filtrate centrifuged. A part of each portion of the sediment was resuspended with a small amount of saline and then inoculated to 3 mice successivly with an addition of antibiotics. The results are shown in Table 10. As seen in the Table, from 3 of 61 cases examined (4.9\%) Toxoplasma has been isolated.

At about the same time Jacobs et al. $(1960 \mathrm{~b})$ isolated Toxoplasma from 8 meat samples out of 50 swine (16\%) obtained from a slaughter house in Baltimore in the U.S. A. The positive case for Toxoplasma in the result of Jacobs was much higher than that of the present authors. He applied the digestive technic for recovering it because he aimed at demonstrating exclusively its cyst form. From the data of the

Table 10. Result of isolation of Toxoplasma from hog diaphragm muscles (Ishii et al., 1960)

\begin{tabular}{cccc}
\hline No. tested & No. positive & per cent positive & Fiducial limits $(0.95)$ \\
\hline 61 & 3 & 4.9 & $1.4 \leqq \mathrm{~m} \leqq 12.0$ \\
\hline
\end{tabular}


Table $11(\mathrm{a})$. Frequency of toxoplasma skin test antibodies among butchers tabulated by age groups (Tanaka et al., 1958a)

\begin{tabular}{cccccccc}
\hline \multirow{2}{*}{$\begin{array}{c}\text { Age group } \\
\text { (years) }\end{array}$} & \multicolumn{3}{c}{ Butchers } & & \multicolumn{3}{c}{ General population } \\
\cline { 2 - 4 } \cline { 6 - 8 } & $\begin{array}{c}\text { No. } \\
\text { test. }\end{array}$ & $\begin{array}{c}\text { No. } \\
\text { posi. }\end{array}$ & $\begin{array}{c}\% \\
\text { posi. }\end{array}$ & & $\begin{array}{l}\text { No. } \\
\text { test. }\end{array}$ & $\begin{array}{c}\text { No. } \\
\text { posi. }\end{array}$ & $\begin{array}{c}\% \\
\text { posi. }\end{array}$ \\
\hline $15-29$ & 91 & 29 & 31.9 & & 21 & & 19.0 \\
$30-49$ & 32 & 20 & 62.5 & & 31 & 8 & 25.8 \\
$50-60$ & 7 & 3 & 42.8 & & 13 & 4 & 30.8 \\
Totals & 130 & 52 & 40.0 & & 65 & 16 & 24.6 \\
\hline
\end{tabular}

Table $11(\mathrm{~b})$. Frequency of skin test antibodies among butchers tabulated by period of employment

\begin{tabular}{lccrc}
\hline \multicolumn{1}{c}{ Period } & $\begin{array}{c}\text { (Average } \\
\text { years of age })\end{array}$ & $\begin{array}{c}\text { No. } \\
\text { test. }\end{array}$ & $\begin{array}{c}\text { No. } \\
\text { posi. }\end{array}$ & $\begin{array}{c}\% \\
\text { posi. }\end{array}$ \\
\hline 1 year or less & $(18.6)$ & 18 & 4 & 22.2 \\
1-10 years & $(23.4)$ & 81 & 28 & 34.6 \\
10-20 years & $(32.4)$ & 11 & 6 & 54.6 \\
20 years or more & $(47.2)$ & 20 & 14 & 70.0 \\
Totals & & 130 & 52 & 40.0 \\
\hline
\end{tabular}

present authors Toxoplasma isolated from swine meat could be either the vegetative or the cyst form, or both of them. At any rate, as the apparently healthy swine meat (pork) was proved to be contaminated with Toxoplasma it can serve as a possible source of human toxoplasmosis.

\section{The Results of the Skin Test among Slauterers}

In 1960 just after the demonstration of Toxoplasma in swine meat, the skin and the dye tests have been performed among 90 slaughterers engaged in the same slaughter house. The results are shown in Table 12. As a control 181 farmers in the vicinity

Table 12. Frequency of toxoplasma antibodies among Shibaura abattoir workers tabulated by age group

(Kobayashi et al., 1961)

\begin{tabular}{lrrrrrrrr}
\hline \multirow{2}{*}{$\begin{array}{c}\text { Age group } \\
\text { (years) }\end{array}$} & \multicolumn{3}{c}{ Skin test } & & \multicolumn{3}{c}{ Dye test } \\
\cline { 2 - 3 } \cline { 6 - 8 } & $\begin{array}{c}\text { No. } \\
\text { test. }\end{array}$ & $\begin{array}{c}\text { No. } \\
\text { posi. }\end{array}$ & $\begin{array}{c}\% \\
\text { posi. }\end{array}$ & & $\begin{array}{c}\text { No. } \\
\text { test. }\end{array}$ & $\begin{array}{c}\text { No. } \\
\text { posi. }\end{array}$ & $\begin{array}{c}\% \\
\text { posi }\end{array}$ \\
\hline $16-20$ & 2 & 0 & & & 2 & 0 & \\
$21-30$ & 43 & 24 & 55.8 & & 44 & 23 & 52.3 \\
$31-40$ & 27 & 23 & 85.2 & & 28 & 18 & 64.3 \\
$41-50$ & 9 & 8 & 88.9 & & 9 & 8 & 88.9 \\
$51-$ & 9 & 6 & 66.7 & & 10 & 6 & 60.0 \\
Totals & 90 & 61 & 67.8 & & 93 & 55 & 59.1 \\
\hline
\end{tabular}

Dilution limit for dye test positive is 1 in 16 or more. 
of Tokyo, 137 workers in the pluck handling trade union and 84 workers engaged in a ham producing feactory, were subjected to the skin test. The results are shown in Table 13.

Table 13. Frequency of skin test antibodies among several occupational groups (Kobayashi et al., 1961)

\begin{tabular}{|c|c|c|c|c|c|c|c|c|c|c|c|c|}
\hline \multirow{2}{*}{$\underset{\text { (years) }}{\text { Age group }}$} & \multicolumn{3}{|c|}{ Abattoir workers } & \multicolumn{3}{|c|}{ Pluck handlers } & \multicolumn{3}{|c|}{$\begin{array}{l}\text { Ham-making } \\
\text { workers }\end{array}$} & \multicolumn{3}{|c|}{$\begin{array}{l}\text { Farmers } \\
\text { (Control) }\end{array}$} \\
\hline & $\begin{array}{l}\text { No. } \\
\text { test. }\end{array}$ & $\begin{array}{l}\text { No. } \\
\text { posi. }\end{array}$ & $\begin{array}{l}\text { (\%) } \\
\text { posi. }\end{array}$ & $\begin{array}{l}\text { No. } \\
\text { test. }\end{array}$ & $\begin{array}{l}\text { No. } \\
\text { posi. }\end{array}$ & $\begin{array}{l}(\%) \\
\text { posi. }\end{array}$ & $\begin{array}{l}\text { No. } \\
\text { test. }\end{array}$ & $\begin{array}{l}\text { No. } \\
\text { posi. }\end{array}$ & $\begin{array}{l}\text { (\%) } \\
\text { posi. }\end{array}$ & $\begin{array}{l}\text { No. } \\
\text { test. }\end{array}$ & $\begin{array}{l}\text { No. } \\
\text { posi. }\end{array}$ & $\begin{array}{l}(\%) \\
\text { posi. }\end{array}$ \\
\hline $16-20$ & 2 & 0 & & 20 & 5 & $(25)$ & 31 & 7 & (23) & 5 & 1 & \\
\hline $21-30$ & 43 & 24 & $(56)$ & 67 & 20 & $(30)$ & 33 & 8 & $(24)$ & 22 & 1 & ( 5$)$ \\
\hline $31-40$ & 27 & 23 & (85) & 33 & 13 & $(39)$ & 7 & 1 & (14) & 41 & 8 & (20) \\
\hline $41-50$ & 9 & 8 & (89) & 7 & 2 & (29) & 3 & 3 & & 60 & 20 & (33) \\
\hline $51-$ & 9 & 6 & $(67)$ & 10 & 6 & $(60)$ & 10 & 6 & $(60)$ & 53 & 24 & (45) \\
\hline Totals & 90 & 61 & (68) & 137 & 46 & $(34)$ & 84 & 25 & $(30)$ & 181 & 54 & (30) \\
\hline $16-30$ & 45 & 24 & (53) & 87 & 25 & (29) & 64 & 15 & (23) & 27 & 2 & (1) \\
\hline $31-$ & 45 & 37 & $(82)$ & 50 & 21 & $(42)$ & 20 & 10 & $(50)$ & 154 & 52 & (34) \\
\hline
\end{tabular}

The results of the skin test showed that the positive incidence among the slaughterers was remarkably higher than that of the others, the former representing $67.8 \%$ and the latters from 30 to $34 \%$.

It is to be noticed that among the slaughterers, relatively young persons, for instance from 21 to 40 years old, showed a nearly equaly high rate of the positive to older ones, whereas among the control groups, particularly among the farmers, the rate of the positive among the younger was smaller as compared with those in higher ages. These facts suggest that the slaughterers have had more chances to contact with a source of the infaction. The results of the dye test can be interpreted that either the active infection was in progress or it had been experienced only recently. Thus these data suggest also that the slaughterers were confronted by a more frequent chance of the infection than the others.

\section{Comment on the Possible Route of Infection}

As is well known, Toxoplasma has two forms, vegetative and cyst. The latter form is generally considered to be the main source of infection, because its resistance under outer environmental conditions is higher than the vegetative. But this fact does not exclude the possibility of the human infection by the direct invasion of the vegetative form through a small lesion in the skin, etc.

The procedure adopted in the present survey of Toxoplasma in swine meat allowed both forms to be recovered, while Jacobs applied for this purpose the digestive technic, which allowed only the recovery of the cyst form, because it killed the vegetative form. Only the cyst form could survive and was isolated through mouse passage. Usually the cyst form is found in the brain of animals, but there is no doubt that the swine meat can be contaminated by both the forms of Toxoplasma.

The mode of the transmission of Toxoplasma from swine meat to human is not 
yet clarified. In Japan people have no custom to eat raw swine meat but there can be a possibility to take it underdone at times. On the other hand it can be considered that its vegetative form can invade directly into the skin through its small legion, and that the human hand would be contaminated with the organisms contained in meat. In the latter case the route of from hand to mouth would be easily concievable, as is the case with the infection of bacillary dysentery, ascaris ova and partly paragonimus metacercaria in Japan.

\section{REFERENCES}

Beverley, J. K. A., Beattie, C. P. \& Roseman, C. (1954): Human toxoplasma infection. J. Hyg., 52, 37-46.

Cole, C. R., Prior, J. A., Docton, F. L., Chamberlain, D. M. \& Saslaw, S. (1953): Toxoplasmosis. III. A study of families exposed to their toxoplasma-infected pet dogs. A. M. A. Arch. Int. Med., 92, 308-313.

Eyles, D. E., Gibson, C. L., Coleman, N., Smith, C. S., Jumper, J. R. \& Jones, F. E. (1959): The prevalence of toxoplasmosis in wild and domesticated animals of the Memphis region. Am. J. Trop. Med. \& Hyg., 8, 505-510.

Farrell, R. L., Docton, F. L., Chamberlain, D. M. \& Cole, C. R. (1952) : Toxoplasmosis. I. Toxcplasma isolated from swine. Am. J. Vet. Res., 13, 181-185.

Feldman, H. A. \& Miller, L. T. (1956): Serological study of toxoplasmosis prevalence. Am. J. Hyg., 64, 320-335.

FISHER, O. D. (1951): Toxoplasma infection in English children. A survey with toxoplasmin intradermal antigen. Lancet, 2, 994-906.

GARD, S. (1951): Toxoplasmosens laboratorie-diagnostik och epidemiologi. Nord. Med., 45, 352-357.

GARNHAM, P. C. C. (1960): World problems in leishmaniasis, amoebiasis, trypanosomiasis and toxoplasmosis. WHO, PA, 101, 60, 70-77.

GrönRoOS, P. (1955): Studies on Toxoplasma and the serology of Toxoplasmosis. Ann. Med. Exper. et Biol. Fenniae, 33 (Suppl. 11), 1-113.

HAMADA, S. (1951): A case of natural infection of toxoplasmosis in a dog. J. Jap. Vet. M. Assoc., 4, 339-342 (text in Japanese).

Hasegawa, S., Tsunematsu, Y. \& TAnaka, N. (1954): Incidence of antibodies for Toxoplasma among men and some domestic animals. Jap. J. Bact., 9, 455-458 (text in Japanese).

HedQvist, T. (1953): Toxoplasma infection at different ages, studied by the skin-test method. J. Hyg., 51, 478-482.

HiRAoKa, T. (1957 a) : A study of toxoplasmosis. (1) The first five cases of human toxoplasmosis in western Japan. Kyushu J. M. Sc., 8, 41-56.

HiRAOKA, T. (1957 b): A study of toxoplasmosis. (2) Further five cases of human toxoplasmosis found in western Japan. Kyushu J. M. Sc., 9, 22-37.

IsHII, S. (1959): Ann. Rep. Co-ope. Res. (Med.) Minist. Educ. (1959), 495 (Quoted from Sato, H., 1959).

Ishi, T., Kobayashi, A., Koyama, T., Kumada, M., Komiya, Y., Fukasawa, T., Saito, M. \& KoshimizU, K. (1960): Studies on toxoplasma (4) A Survey of pork meat samples for the presence of toxoplasma. Reported at the Local Meeting of Jap. Soc. Parasit.

JACOBS, L. (1953): The biology of Toxoplasma. Am. J. Trop. Med. \& Hyg., 2, 365-389.

JACOBS, L. (1957): The interrelation of toxoplasmosis in swine, cattle, dogs, and man. Pub. Health. Rep., 72, 872-882.

JACOBS, L., JONEs, F. E. \& MeLton, M. L. (1952): The survival of Toxoplasma gondii in various suspending media. J. Parasit., 38, 293-297.

JacoBs, L., Melton, M. L. \& COOK, M. K. (1955): Observation on toxoplasmosis in dogs. J. Parasit., 41, 353-361. 
JAcobs, L., Remington, J. S. \& Melton, M. L. (1960 a): The resistance of the encysted form of Toxoplasma gondii. J. Parasit., 46, 11-21.

JACOBS, L., Remington, J. S. \& Melton, M. L. $(1960 \mathrm{~b})$ : A survey of meat samples from swine, cattle, and sheep for the presence of encysted toxoplasma. J. Parasit., 46, 23-28.

Johno, K., Koike, I., Sano, R., TAKada, S., Shingaki, I. \& Aoki, J. (1961): Studies on the clinical finding and epidemiological survey of two cases of toxoplasmosis. Jap. J. Parasit., 10,510 (text in Japanese).

Kagawa, S., Yoshino, T., Abe, S., Mori, T., Oikawa, T., Kaneko, Y., Kobayashi, K., Ashigari, H., Sugiura, A., Tsunematsu, Y., Saito, Y., Yanagisawa, K., Ogura, M., NAOE, T. \& KAMIZUKA, E. (1954): Studies on toxoplasmosis. On the toxoplasmin intradermal reaction. Jap. M. J., 1950, 4305-4309 (text in Japanese).

KeLleR, W. \& Vivell, O. (1952): Über die klinische und epidemiologische Bedeutung des Antikörpernachweises gegen das Toxoplasma gondii mit dem Sabin-Feldmanschen Farbtest. Zeitschr. Kinderh., 71, 42-60.

Kobayashi, A., Ishil, T., Koyama, T., Kumada, M., Komiya, Y., Kanai, T., Fukasawa, T., Koshimizu, K., Saito, M., OnOdA, T. \& Hanaki, T. (1961): Studies on toxoplasma. (5) Incidence of toxoplasma antibodies among abattoir workers, ham-making workers, pluck handlers and farmers. Jap. J. Parasit., 10, 508-509 (text in Japanese).

KoIke, T., Tsujirama, T. \& SenAGA, R. (1959): A case of human toxoplasmosis with the chief complaint of headache and slight fever, and on the toxoplasma strain isolated from the patient. (A infantile toxoplasmosis assumed to be infected by dogs). Shonika Shinryo, 22, $1380-1385$ (text in Japanese).

Koike, T., UedA, H. \& Yamato, J. (1960): Toxoplasmin and Sabin-Feldman dye test in healthy men and tuberculosis children. Nissin Igaku, 47, 130-134 (text in Japanese with English summary).

MAtsubayAshi, H. (1959): Morphology and immunology of Toxoplasma gondii. Tokyo M. J., 76, 251-257 (text in Japanese).

MAtsubayashi, H. (1960): Epidemiological survey on human toxoplasmosis with some experiments on the chronic toxoplasma infection. Ann. Rep. Co-ope. Res. (Med.) Minist. Educ. (1959), 522-523 (text in Japanese).

MATSUbayashi, H., SAito, S. \& NAKAyAMA, I. (1961): Epidemiological survey on human toxoplasmosis and on study of the cyst form of toxoplasma. Ann. Rep. Co-ope. Res. (Med.) Minist. Educ. (1960), 540-541 (text in Japanese).

MiNE, N. (1911): Observation on protozoan parasites in Japan. Gun-I-Dan Zasshi, 27, Suppl., 2, 1-68 (text in Japanese).

Miyagawa, Y., Shinohara, S,. Yoshida, H., Nagabori, Z., Ishiwaka, D., Inagami, T., MrYAGAWA. E. \& TANUMA, I. (1954): Toxoplasmosis in Japan. (1) On Toxoplasma gondii found in cerebrospinal fluid of hydrocephalus children. Shinryo-no-Jissai, 5, 575-580 (text in Japanese).

MrYAZAKI, I. \& HIRAOKA, T. (1957) : Toxoplasmosis to be duly considered in Japan too. Jap. M. J., 1722, 38-51 (text in Japanese).

MryaZAKI, I., IshiI, Y. \& YAmAmoto, I. (1960) : Survey on human toxoplasmosis. Ann. Rep. Co-ope. Res. (Med.) Minist. Educ. (1959), 523 (text in Japanese).

MiYAZAKI, I., IShII, Y., YAMAMOTO, I. \& HATTORI, I. (1961): Survey of human toxoplasmosis and effects of several medicaments on toxoplasmosis. Ann. Rep. Co-ope. Res. (Med.) Minist. Educ. (1960), 541-542 (text in Japanese).

Mochizuki, H., Chisuwa, R., Asakawa, Y. \& Noguchi, M. (1960): Studies on toxoplasmosis. Results of dye test on abattoir workers and domestic animals in Shizuoka Prefecture. Reported at the Local Meeting of Jap. Soc. of Parasit.

NicOlle, C. \& MANCEAUX, L. (1908): Sur une infection à corps de Leishman (ou organismes voisins) du gondi. Compt. rend. Acad. Sc., 147, 763-766.

Nobuto, K., Suzuki, K., Omuro, M. \& Ishi, S. (1960): Studies on toxoplasmosis in domestic 
animals. Serological response of animals to experimental infection and successful application of complement fixation inhibition test for exposure of infected herds. Bull. Nat. Inst. Animal Health, 40, 29-52.

OTsURU, M. (1961) : Unpublished, personal communication.

Otsuru, M., TANAKA, H., Kojima, M. \& ShinokAwa, I. (1958): A case of human toxoplasmosis. On the isolation of Toxoplasma gondii (Watanabe strain). Sogo Rinsho, 7, 10791086 (text in Japanese).

Otsuru, M., TANaka, H. \& Ozima, S. (1959): Toxoplasmosis in Niigata Prefecture. Jap. J. Parasit., 8, 347 (text in Japanese).

Otsuru, M., Shinokawa, I., Tanaka, H. \& Kojima, S. (1960 a): Survey of toxoplasmosis in Hokuriku district. Ann. Rep. Co-ope. Res. (Med.) Minist. Educ. (1959), 524-525 (text in Japanese).

Otsuru, M. \& Hasegawa, K. (1960 b) : Studies on toxoplasmosis. Reported at the Local Meeting of the Jap. Soc. of Parasit.

Otten, E., Westphal, A. \& Kajahn, E. (1951): Zur Epidemiologie der Toxoplasmose. Der Hund als Infektions quelle des Menschen. Klin. Wschr., 29, 343-346.

Prior, J. A., Cole, C. R., Docton, F. L., Saslaw, S. \& Chamberlain, D. M. (1953): Toxoplasmosis. 4. Report of three cases with particular reference to asymptomatic parasitemia in a young woman. A. M. A. Arch. Int. Med., 92, 314-320.

ProwazeK, S. (1910): Parasitische Protozoen aus Japan, gesammelt von Herrn Dr. Mine in Fukuoka. Arch. Schiffs. Trop. Hyg., 14, 297-302.

RAWAL, B. D. (1959): Toxoplasmosis. A dye-test survey on sera from vegetarians and meat eaters in Bombay. Trans. Roy. Soc. Trop. Med. Hyg., 53, 61-63.

SABIN, A. B. \& Feldman, H. A. (1949): Skin reactions to toxoplasmic antigen in people of different ages without known history of infection. Pediat., 4, 798-804.

Sabin, A. B., Eichenwald, H., Feldman, H. A. \& Jacobs, L. (1952): Present status of clinical manifestations of toxoplasmosis in man. Indication and provisions for routine serologic diagnosis. J. A. M. A., 150, 1063-1069.

SAITO, S. (1961): Surveys on the toxoplasma infection in patients of central nervous system and other disturbances Jap. J. Parasit., 10, 509 (text in Japanese).

SATO, H. (1959): Toxoplasmosis. J. Jap. Vet. M. Assoc., 12, 473-477 (text in Japanese).

SATO, H. (1961): Unpublished data, personal communication.

Sato, H., Saeki, Y., Muto, T., Oishi, I., Kobayashi, S., Miyamoto, Y. \& Ochi, Y. (1958) : Studies on toxoplasmosis in domestic animals. 1. Isolation of Toxoplasma gondii from porcine \& canine cases. Jap. J. Vet. Sc., 20, 213-221 (text in Japanese with English summary).

Shimada, K., Ueki, H. \& Murakami, H. (1956): Bulletin of the Tokyo-to Laboratories for Medical Sciences, 92, 32-39 (text in Japanese).

SHIMIZU, F. (1961): Personal communication.

Shimizu, F., Hashimoto, M., Fujita, K., Kawakami, S., Murayama, N., Higaki, H., Seo, U., Kimura, M., Yokono, S. \& Nakamura, J. (1958 a) : Studies on congenital toxoplasmosis especially on its causative mechanism. Ochanomizu M. J., 6, 1037-1040 (text in Japanese).

Shimizu, F., Hashimoto, M., Fujita, K., Kawakami, S., Kobayashi, M., Takayama, S., Yoshino, T., Someya, H., Ishikawa, C., Okamoto, Y., Masuda, E., Muto, J. \& AMAKASU, S. (1958 b): Distribution of antibodies to Toxoplasma gondii in normal human sera. Jap. J. Hyg., 13, 173-177 (text in Japanese).

SuzUKI, K. (1961): Personal communication.

SuZUKI, K., ITO, S. \& FujiTA, J. (1960): Studies on toxoplasmosis in domestic animals (4) Epidemiological survey on swine toxoplasmosis. Suiyokai Kiji, 9, 29, (text in Japanese).

TAkATsu, T. \& FuruYA, T. (1958): Additional statement at the 27th Annual Meeting of the Japanese Society of Parasitology. 
TANAKa, H., Kojima, S. \& MAItani, T. (1958 a): Study on toxoplasmosis. I. Toxoplasmin test of the families keeping pet dogs and of the butchers in Niigata City. Med. \& Biol., 47, 238-242 (text in Japanese).

TANaka, H., Kojima, S. \& Maitani, T. (1958 b) : Study on toxoplasmosis. II. Sabin-Feldman dye-test of the pet dogs and domestic animals in Niigata Prefecture. Med. \& Biol., 48, 142146 (text in Japanese).

Tanaka, H., Ikuzawa, M., Johno, K., Takeyama, K., Sano, R. \& Iwazaki, T. (1961): Isolation of Toxoplasma gondii from a patient of headache and a embryo of hydrocephalus. Jap. J. Parasit., 10, 509-510 (text in Japanese).

TsujI, S., ARAI, H. \& SENAGA, R. (1958): The sero-immunological surveys of toxoplasmosis in the cases of abortion, pregnancy, psychopathy and mental deficiencies. Nisshin Igaku, 45, 447-455 (text in Japanese with English summary).

Tsunematsu, Y., NaOe, T., Saito, M., Yanagisawa, K., Niki, W. \& OguRa, M. (1958) : Studies on toxoplasma (7) Serological surveys of toxoplasmosis on normal human populations, and some patient groups of diseases of eye-ground, central nervous system or other disturbances. Tokyo M. J., 75, 223-225 (text in Japanese).

VAN ThIEL, P. H. \& VAN DER WAAIJ, D. (1956): The significance of pseudocysts in the oral infection of man and animals with Toxoplasma gondii. Doc. Med. Geograph. Trop., 8, 392-396.

Weinman D. (1952): Am. Rev. Microb., 6, 291. (Quoted from Sato, H., 1959).

Weinman, D. \& ChandleR, A. H. (1956): Toxoplasmosis in man and swine. An investigation of the possible relationship. J. A. M. A., 161, 229-232.

WILDFÜHR, G. (1954): Toxoplasmose. G. Fisher, Jena, pp, 176.

WolF, A. \& Coẉen, D. (1937): Granulomatous encephalomyelitis due to an Encephalitozoon Encephalitozoic encephalomyelitis). A new protozoan disease of man. Bull. Neurol. Inst. New York, 6, 306-371.

Wolf, A., Cowen, D. \& Paige, B. H. (1939): Toxoplasmic encephalomyelitis. (3) A new case of granulomatous encephalomyelitis due to a protozoon. Am. J. Pathol., 15, 657-694.

YAMAmoto, I. (1959): Studies on Toxoplasma gondii. Some cases of human and hog toxoplasmosis in Kyushu. Fukuoka Acta med., 50, 3888-3909 (text in Japanese with English summary).

YAMAMOTO, S., IshidA, K., Fujiwara, K., Ito, S. \& UedA, K. (1955): Studies on toxoplasmosis in animals. 2. Report on two canine cases. Jap. J. Vet. Sc., 17, 79-85.

\section{Other Publications Related to Toxoplasmosis in Japan}

FujIWARA, T. (1941): Demonstration of Toxoplasma and Leucocytozoon in birds. Proceedings of Annual Meeting of Jap. Soc. Parasit., 13, 22-23 (text in Japanese).

HIRATO, K. (1939): Notes on two cases of toxoplasmosis observed among raccoon-dogs in the vicinity of Sapporo. Jap. J. Vet. Sc., 1, 544-552 (text in Japanese).

KoIKE, T. (1959): On Sabin-Feldman's dye-test in cases of ocular diseases probably caused by toxoplasma and on the strain isolated from two cases of hydrocephalus. Jap. J. Parasit., 8, 347-348 (text in Japanese).

KoIKE, T. (1960): Studies on the experimental infections of Toxoplasma gondii in dogs. (2) Comparison of Sabin-Feldman dye test and complement fixation test. Nissin Igaku, 47, 322336 (text in Japanese with English summary).

KoIKE, T., TsuJI, S. \& ARAI, H. (1958): Toxoplasma gondii isolated from a guinea pig. Nisshin Igaku, 45, 379-383 (text in Japanese with English summary).

Koike, T., Miyauchi, K., Iida, A., Ishikawa, K., Senaga, R., Osano, M. \& Yogo, T. (1959 a) : A case of infantile toxoplasmosis with hydrocephalus, and on the toxoplasma strain isolated from the patient. Shonika Shinryo, 22, 1369-1374 (text in Japanese).

KoIKe, T., ODA, H., IIDA, A. \& MrYAUCHI, K. (1959 b) : A case of toxoplasmic hydrocephalus with negative dye test, and on the toxoplasma strain isolated from the patient. Shonika 
Shinryo, 22, 1375-1379 (text in Japanese).

Koike, T., OGawa, H. \& Fukushima, I. (1959 c): A case of infantile toxoplasmosis with ophthalmoplegia externa and on the strain isolated from the patient with special reference to the observation on post treatment course. Shonika Shinryo, 22, 1386-1394 (text in Japanese).

KomIYA, Y. (1961): Toxoplasmosis. Yakkyoku, 12, 871-875 (text in Japanese)

Kumada, M., Koyama, T., Kobayashi, A., Hashimoto, I., KomiYA, Y. \& IshiI, T. (1961) : The comparative resistance of the encysted form and proliferative form of Toxoplasma gondii to a lower temperature (unpublished).

Matsubayashi, H., Senaga, R., Ootsuka, H., Watanabe, Y., Tazaki, H., Ozawa, A., KaGAMI, K. \& Hamano, K. (1956): Studies on toxoplasmosis. (2) A case of toxoplasmic encephalitis. Jap. M. J., 1674, 23-26 (text in Japanese).

Matsubayashi, H., MochizUKI, H. \& YAMADA, J. (1957) : On a strain of toxoplasma detected from a pig in Shizuoka Prefecture. Nisshin Igaku, 44, 368-372 (text in Japanese with English summary).

Mryagawa, Y., Miyagawa, E., Ishihana, D., Yoshida, H., Nagabori, Z., Shinoda, S. \& INAGAMI, T. (1955): Toxoplamosis in Japan. (2) Further study on isolating toxoplasmas from hydrocephalus patients and sick fowls, and on the toxoplasma strains isolated from them. Shinryo-no-Jissai, 6, 270-275 (text in Japanese).

OTsuru, M., TANAKA, H. \& KoJima, M. (1959): Epidemiological survey of toxoplasma infections among inhabitants and domestic animals in Hokuriku district. Ann. Rep. Co-ope. Res. (Med.) Minist. Educ. (1958), 492-493 (text in Japanese).

SENAGA, R. \& TAZAKI, H. (1956): Studies on toxoplasmosis. I. Result of Sabin-Feldman dye test on children. Jap. M. J., 1673, 28-26 (text in Japanese).

SHImizU, K. (1958): Studies on toxoplasmosis. I. An outbreak of toxoplasmosis among hares (Lepus timidus ainu) in Sapporo. Jap. J. Vet. Res., 6, 157-169 (text in English).

ShimizU, F. \& Hashimoto, M. (1961): Surveys on toxoplasmosis. Ann. Rep. Co-ope. Res. (Med.) Minist. Educ. (1960), 543 (text in Japanese).

TAZAKI, H. (1954): Surveys on toxoplasma in rats, dogs and sparrows. Jap. J. Parasit., 3, 26 (text in Japanese).

Tsunematsu, Y. (1961): Toxoplasma gondii, on its biological and medical aspects. Shizen, $16,22-29$ (text in Japanese).

Tsunematsu, Y., Shimagaki, M., Saito, M., NaOe, T., Yanagisawa, K., Niki, W. \& OGURA, M. (1958): Studies on toxoplasma. (6) On the DR strain of toxoplasma isolated from a wild rat. Tokyo M. J., 75, 217-221 (text in Japanese).

YAMAmoto, S., IshIDA, K. \& FuJIWARA, K. (1955) : Studies on toxoplasmosis in animals. I. Report of a case in cat. Jap. J. Vet. Sc., 17, 13-18 (text in English). 